\title{
Don't Let Fear Guide Your Path
}

\author{
Henry B. Balfanz, Alma College, USA
}

\begin{abstract}
Founder of BRICKK, a fitness lounge, Kathy Pavlik was determined to create a friendly, healthy, non-intimidating atmosphere where clients would feel welcome. Pavlik believes 'fear' causes many people to begin then quit working out. Inspired by her own experiences, Pavlik created a new concept in the health club business in Alma, Michigan. Now that BRICKK is a reality, the next steps need to be determined in the effort to make the fitness lounge a financial success. Pavlik is considering a number of marketing strategies in order to build up attendance in the classes. She's also considering marketing ideas on how to increase business with her lunches/smoothie bar and possible lunch delivery within the county.
\end{abstract}

Keywords: Weight Loss Industry; Health Club Marketing; Marketing Case Study

Suggested Courses: Marketing and Society; Cases and Applications in Marketing

\section{INTRODUCTION}

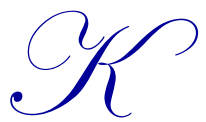

athy Pavlik had a goal. "I just wanted to be able to get down on the floor and play with my kids." Weighing nearly 300 pounds, that simply was not a possibility. That made her sad and despondent.

However, the forty something Alma, Michigan resident was determined to do something about it. Not unlike a lot of other weight loss hopefuls, she had tried the many plans to losing weight. "I didn't come from a very fit family," Pavlik says, "so exercise and discipline didn’t come easily for me."

After her first child was born in 2006, she put on a large amount of weight. She decided to join a weight loss program at an area hospital. She was successful in losing 45 pounds, but she felt she needed to lose more. And, she didn't enjoy the 'partial meal replacement' aspect of the program as she simply disliked the food. Four years later, Pavlik had her second child and, unfortunately, gained all the weight back and more.

Her story is a familiar one. Every overweight person is looking for the magic formula to losing weight. According to author and marketing consultant Martin Lindstrom, Americans spend over $\$ 100$ billion on fast food every year (Small Data, 2016) with an estimated \$42 billion dollars a year spent on weight loss foods, products, and services, according to the website Medicinenet. (Harbolic, 2014). And it's always a question as to whether the weight loss will be permanent or not.

"The average American, adult and child alike, is bombarded with corn fed beef, high fructose corn syrup, refined sugars and starches and dangerous trans fats. Even that ubiquitous jar of peanut butter is guilty, harboring a heavy dose of hydrogenated fats," writes Dr. Nicholas Perricone in his Dieters Dilemma blog in the Huffington Post (2011). No wonder obesity continues to be one of America's woes.

Pavlik felt that if she could find the solution to her own weight loss issues she would share her solution with others just like herself. This was another important goal of the entrepreneur.

\section{MEETING THE TRAINER WHO WOULD CHANGE HER LIFE}

At a loss as to how to go about losing weight (not eager to try a fad diet after her previous experience), Pavlik was introduced to a trainer who was also a boxing instructor. "This was a stroke of luck. He got me started at home with a sit up bench and weights." The trainer urged Pavlik to join a group training class he taught at a local health club. 
Pavlik was determined to succeed on her own but relented. "I had told him that if I lost fifty pounds on my own, I would join. And I did!”

While she understood the inspiring nature of group fitness, she felt very self-conscious in that class. She knew this atmosphere wasn't for her long-term. "Lots of people are intimidated and scared in group fitness. They join a program not knowing anything about fitness; they feel looked at and critiqued. They are afraid to fail; thus fear 'guides their path' through the fitness and weight loss process. And nobody enjoys that."

One personal trainer, Marc Pogorzelski of Upper Echelon Fitness and Performance lists the three top reasons as to why people never start an exercise program as 1) poor expectations 2) self-perception and 3) body image. Thus, those who do enter exercise programs may enter the program with an already negative state-of-mind (www.iamupperechelon.com, 2017).

Pavlik believes, after talking to many of her friends, after starting an exercise program, that most health clubs tend to intimidate the new member and as a result, have a large turnover in membership which could be avoided with a little more sensitivity and understanding of the fear a new member might be facing.

\section{INTRODUCING BRICKK, A FITNESS LOUNGE}

Put simply, Pavlik's goal in creating BRICKK, was to encourage an atmosphere where it would "make it easy to walk through the door and help someone like me". She wants the clients to feel comfortable and work at their own pace in accomplishing their goals, no matter what the goals are, without letting fear guide their path.

She went looking for a building. She found one in a high traffic area.

BRICKK (name inspired by the 1977 Commodores hit "Brickhouse") is a 3600 square feet remodeled facility (see Figure 1) on two floors along fast food row (between McDonalds and Burger King) in Alma, Michigan, a town of 9383 residents according to the 2010 census (www.census.gov/2010census/data).

You won't find the facility full of exercise machines, as you might in practically all health clubs. That's another unique aspect of BRICKK. You'll only be able to participate in group fitness classes.

Pavlik opened the club in April 2016. Attendance at group fitness class continues to grow, with the more popular classes approaching and sometimes exceeding the suggested limit of 25 participants per class.

Figure 1. BRICKK, a fitness lounge.

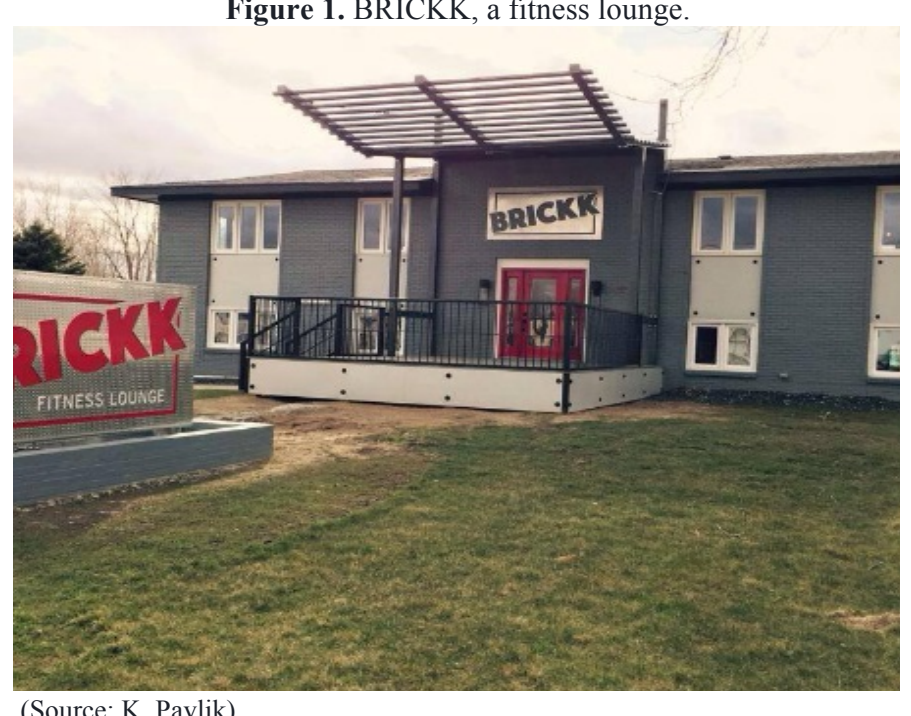

(Source: K. Pavlik) 


\section{TARGET MARKET AND DIFFERENTIATING PHILOSOPHY}

Pavlik tends to think of her target market as not demographically defined, but rather defined by self-perception. "We are looking to help the person of any age or lifestyle, who is obese, struggling, with the feeling that he or she is trapped in his or her own body. We are trying to attract beginners who have fitness and weight aspirations, but have no idea how to get started on a healthy path."

She has strong feelings about helping her customers. "I believe there are all different sizes of healthy and happy. We don't force upon our customers what we want. If they only want to lose ten pounds, we will set that as our goal for them. And then we'll use our heart, love, and compassion to help them reach this goal," Pavlik adds.

BRICKK differentiates itself from other clubs by providing a more caring, less aggressive approach to fitness and weight loss.

When asked to describe her current customer in more conventional demographically defined terms, Pavlik says "females 30 to 60 years of age." $25 \%$ of the 41 million members of health clubs in America are over the age of 55, claims Jenn Fusion of the website Chron (Fusion, n.d.) "Our membership tends to be younger," according to Pavlik. She also knows that $95 \%$ of her customers are female. She is debating as to whether she needs to spend the time and money it would take to attract more males to BRICKK. She feels that might require an investment in weight equipment and machines. She's not ready nor does she have the space that would be required.

\section{THE COMPETITIVE MARKET ENVIRONMENT}

Despite its small size, the town of Alma (and surrounding Gratiot County) offers some formidable competition in the fitness club business. Nearby St. Louis, Michigan offers a similar competitor to BRICKK, in that the club offers only exercise classes; the club has been in business longer than BRICKK. County seat Ithaca, ten miles south on state highway 127 , has a facility with a gym which is quite popular.

Mt. Pleasant, fifteen miles north on 127, is a university community (Central Michigan University). It has a good number of health and fitness clubs but Gratiot County residents are not as likely to make the drive, according to Pavlik.

In Alma itself, BRICKK faces competition from Snap Fitness and Endurance Fitness, both 24 hour clubs. Alma College, a school of 1400 students, boasts the Stone Center for Recreation, complete with a track but only features a couple of fitness classes while school is in session. Pavlik works closely with the Stone Center, offering discounted passes to BRICKK to the members. Alma residents, as well as students, faculty, and staff of Alma College, are members of the Stone Center.

The 24 hour clubs are older than BRICKK but are still fairly new to the area. The 'never close' philosophy allows area shift workers and younger members who may be in school the opportunity to work out on their own schedule. Endurance Fitness offers exercise classes similar to BRICKK. Snap Fitness and Endourance Fitness clubs make month-to-month memberships available, according to their websites. Both clubs are close geographically to BRICKK and feature exercise machines.

\section{CLASSES AND INSTRUCTORS}

BRICKK offers a variety of classes ranging from stretching (Yoga) to pulse raising (Boxing) to weights (Kettlebells). Classes are scheduled starting at 5:15 am thru $8 \mathrm{pm}$ some days. In order to avoid overfilling the class, Pavlik wants participants to reserve a spot in advance. She has them use the MINDBODY app in order to do so.

Pavlik has eight certified and experienced instructors, "all passionate and here to help people. They understand my philosophy of "make it easy to walk through the door' ", as she stresses it on a daily basis (Figure 2). Authors Christopher Lovelock and Jochen Wirtz believe that " service personnel [such as instructors] serve as a source of 
customer loyalty and competitive advantage." And that from a customer's point-of-view, "service personnel... signifitcantly determine service qualty." (Services Marketing, 2007)

In addition to the classes already mentioned, other classes include: kickboxing, 30 minute ABS, Boxing fusion, Chisel, Hip Hop Dance, Stretch and Tone, Circuits, Boxing, and Strength. "We may change class times from month to month, and we are exploring adding others," according to Pavlik, as well as perhaps adding more classes to the already popular and often full favorite classes.

\section{PRICING}

BRICKK's pricing is very afffordable. After researching pricing in other markets, such as Grand Rapids, Lansing, and Detroit, as well as in her own market, Pavlik decided to give her participants a number of options.

Pay by drop-in at $\$ 10$ a class. Buy a punchcard for ten sessions for $\$ 80$. Monthly membership for unlimited classes is $\$ 88$ a month. Three months at $\$ 68$ a month. No fees charged for cancelling. The Senior Special (over 60) is $\$ 58$ a month, available year around. When it comes to comparing pricing with her Gratiot County competitors, Pavlik realizes at initial glance, BRICKK may appear more expensive. According to Pavlik, however, "we have no surprise add-on fees, and the longest membership we will offer will be three months. We don't want clients to feel they are trapped into a long term contract."

Pricing is the key to the kind of clientele you attract, believes Steve Main, author of TOTAL Health Club Management (Main, 2006). He writes, "many advocate selling very low price or discounted memberships to obtain volume. Others advocate high prices and selling value. Anyone who says one way or the other is always better is not an expert, because one size does not fit all."

\section{CHILD CARE}

Finding child care for only an hour or two each day is difficult for most parents. "We offer supervised child care. We also have a camera in the childcare area so participants can watch while they work out," Pavlik says. There is no charge for the child care.

\section{SMOOTHIE AND LUNCH LOUNGE}

Pavlik believes "food is $90 \%$ of the weight loss battle." That's why she installed a smoothie bar when she opened in April 2016 and has since added other items.

Enter 'Smoothies for Weight Loss' into GOOGLE and you'll get 5.8 million results (www.google.com, 2016). An article found on the fitness website Popsugar (Sugar, 2015) lists five reasons why smoothies are the best breakfast for weight loss:

- They're filling

- Consider your sweet tooth satisfied

- You choose the calorie count [based on ingredients]

- They're protein packed

- They're crazy quick

- They're crazy quick

Pavlik believes in this philosophy as well. She offers a choice of eight different flavors, available in two sizes. They're served in a 'to go' cup so class participants can take them with them if they like. Customers are also given punch cards so they can receive a free smoothie after they've purchased ten. Smoothies (and lunch) are served six days a week much to the delight of clients and Alma residents who simply want to stop and have a smoothie, lunch at the lounge, or to take them with her. Pavlik always advertises smoothies and food in all of her marketing to attract even more people who will also be tempted to join the club. The lunch menu is growing and now includes salads, wraps, paninis, and soups. She plans to put the menu online and offer delivery to businesses and residents of 
Gratiot County. She is considering free delivery to the Alma community with a five dollar delivery charge to other parts of the county; a total population of 42,476 (www.census.gov/2010/data).

\section{STAFF}

In addition to her eight instructors, Pavlik maintains a small staff who keep the business thriving. She has her right hand person Carla, as well as her computer person Alisha. Fixing the smoothies and food, Pavlik has the BRICKK girls. "I'm thankful for a good staff of loyal employees,' Pavlik adds. "They give me time to focus on growing the business."

Figure 2. Kathy Pavlik (center) and her instructors.

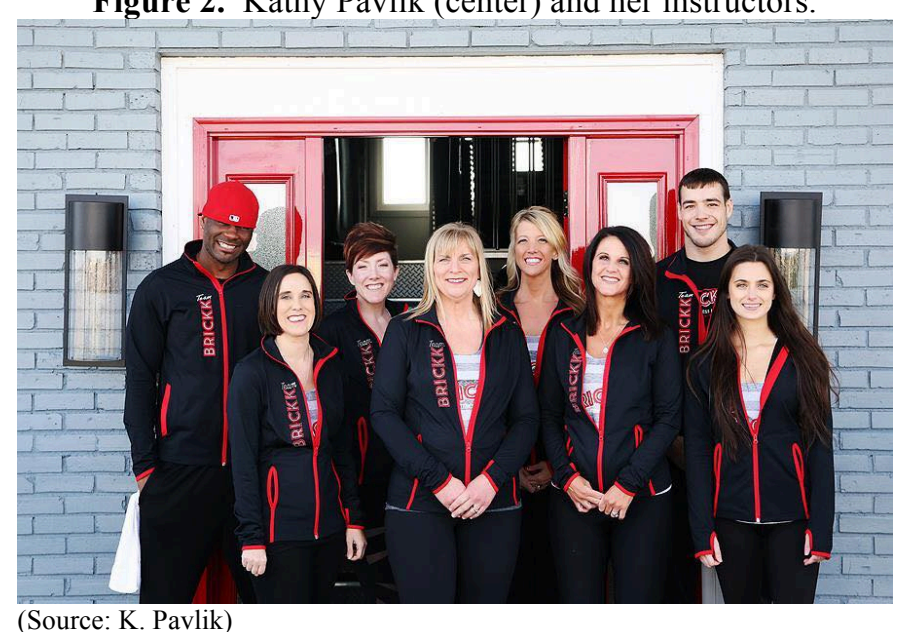

\section{PROMOTIONAL MIX}

In an effort to reach the target market, Pavlik has tried a number of traditional media approaches. She has three billboard locations, on busy state highways 127 and 46. She's also tried newspaper and radio, but has not felt any impact from the local electronic media advertising. With her feeling that her target is more behavioral in nature, it may be difficult to reach the target market through traditional media.

In addition, Pavlik is very much into social media, coordinated by one of her instructors. She's present on Facebook, Snapchat, and Instagram. Pavlik believes it is probably easier to reach her target through social media, as those with an interest in losing weight and/or getting into shape are the people who are visiting her social media sites.

She's also hoping to increase membership during the important winter months. New Year's resolutions are a strong driver of membership growth for health clubs. "I'm hoping to get them in on the promise of fulfilling their resolution, then keeping them because they see progress and really enjoy our classes," adds Pavlik.

When it comes to personal selling and sales promotion, Pavlik takes a laidback approach. "When someone comes in, we give them the grand tour. We also share a schedule of classes, as well as explain our pricing. We will then give them a free class coupon so they can try us out once and then let them make the decision on their own. No hard sell. We keep it very unaggressive."

\section{GRASSROOTS PUBLIC RELATIONS APPROACH}

Pavlik is developing a strategy where she approaches potential customers one at a time. "Our plan is to go door to door to businesses throughout Gratiot County. We will deliver a brochure about our concept and our class schedule, 
plus a menu to each department of every business and personally invite them to come try BRICKK." In addition to businesses, Pavlik will target schools and doctors within the county with the brochures and personal delivery of menu items. This grassroots style of marketing, i.e. one on one with a personal invitation, has the possibility of growing her membership in a fast fashion.

When it comes to targeting younger customers, Pavlik intends to create Teen BRICKK night and the Teen BRICKK discount card. She also works with Alma College students, as mentioned, by offering the Alma College BRICKK Student discount card.

\section{PROGRESS}

BRICKK is now past a year in existence. Overall, she's happy with the progress of BRICKK, considering she had no idea what to expect in terms of acceptance by the community when she opened. "It's been exciting. We have new potential customers coming in for tours daily," she reports. After her first year of operation, she's beginning to see some trends that will help her make decisions on future plans in all areas of her business.

Her average class attendance sits at approximately $50 \%$ of class capacity (capacity is 25 ). As with any average, there are some classes that are close to capacity on a regular basis. Others may only have four or five participants. While it would make financial sense to cancel the smaller attendance classes, Pavlik is aware that many can only attend at the time the class is offered. As she has built her business around the fact that she wants to have an accepting, understanding, and accommodating philosophy, she's hesitant to cancel classes at this point in her business's tenure.

When it comes to her smoothie bar and lunch business, Kathy is amazed by the number people who stop by simply to pick up a smoothie. "The number of people stopping to buy a smoothie has more than tripled in the past year. Word of mouth has spread and it continues to grow. Now if we could get more of them to stay and have lunch or take lunch with them, we'd see some good revenue growth in that area," Pavlik reports.

\section{THE FUTURE}

When attendance of some classes reaches capacity or when one group is waiting for the previous class to end, attendees are not able to get into her parking lot and have had to park in the nearby fast food lots. "We may have to add more class sessions and possibly add more parking. The growth has been spectacular considering how new we are."

Growing pains are a challenge for every new successful business. Pavlik is planning as far down the road as she possibly can. She started BRICKK as a way to fulfill her goal of helping others in the same situation she was in; she hopes to be able to share her success with many others in the future, using the same non intimidating style of working with clients.

\section{AUTHOR BIOGRAPHY}

Henry Balfanz is an Assistant Professor of Business Administration at Alma College in Alma, Michigan. Balfanz also taught Marketing at Bradley University in Peoria, Illinois and Northern Michigan University in Marquette, Michigan. He has also taught at Vysoka Skola Ekonomicka in Prague, Czech Republic on seven occasions. Prior to teaching, Balfanz was an Executive in the broadcast, newspaper, and advertising industries. Balfanz holds a Bachelor of Science in Broadcast Management from Southern Illinois University at Carbondale and a Masters of Business Administration from Bradley University. E-mail: Balfanzhb@alma.edu.

\section{REFERENCES}

Center for New Media and Promotions (C2PO). (n.d.). US Census Bureau 2010 Census. Retrieved February 10, 2017, from http://www.census.gov/2010census/data/

Crane, F. (2013). Marketing for Entrepreneurs. Sage Publications 
Fusion, J. (n.d.). What is the Target Market for Fitness Gyms? Retrieved from http://smallbusiness.chron.com /target-marketfitness-gyms-3354.html).

Lindstrom, M. (2016). Small Data. Hodder \& Stoughton

Harbolic, B. (2014). Diet Plans \& Programs: The "Skinny" on Popular Diet Plans. Retrieved from http://www.medicinenet.com/diet_plans_and_programs/article.htm

Lovelock C. \& Wirtz J. (2007) Services Marketing. Pearson Prentice Hall

Main, S. (2006). Total Health Club Management. Singapore: The Changing Point.

Neck, Neck \& Murray (2018) Entrepreneurship: the practice and mindset. Sage Publications

Peragine, J. (2008). Personal Training Business. Atlantic Publishing Group

Perricone, N. (2011, November 17). The Dieter's Dilemma [Blog post]. Retrieved from http://www.huffingtonpost.com/drnicholas-perricone/the-dieters-dilemma_b_246144.html, Nov 17, 2011

Pogorzelski. M. (2017, January 18). 3 Reasons Why People Never Start an Exercise Program [Blog post]. Retrieved from http://www.iamupperechelon.com/3-reasons-why-people-never-start-an-exercise-program/

Sugar, J. (2015). 5 Reasons Smoothies Are the Best Breakfast For Weight Loss. Retrieved from http://www.popsugar.com/fitness/Why-Smoothies-Good-Weight-Loss-38826806

\section{DISCUSSION QUESTIONS/REQUIREMENTS}

1) How would you describe the pricing for classes at BRICKK?

2) Is going door-to-door an effective use of Pavlik's time? Do you feel it will be effective in generating new members? Perhaps she should hire someone to do it for her?

3) Should BRICKK adjust its target market? How would you define the clientele in psychographic terms?

4) How do you assess the adequacy of the elements of the marketing mix (7 Ps for service marketing: price, place, promotion, product/service, people, process, physical evidence)?

5) Should Pavlik consider adding exercise machines to broaden her potential clientele? Why or why not?

6) Considering that some classes are reaching capacity, should Pavlik raise prices? Why or why not?

Educators: Teaching notes provided upon request. 


\section{NOTES}

